\title{
EFL Saudi Undergraduates' Tenses Errors in Written Discourse Due to Interlingual and Intralingual Interference
}

\author{
Muteb Ali Alzahrani \\ College of Sciences and Arts, Muhayil Asir \\ King Khalid University, Kingdom of Saudi Arabia \\ E-mail: muteb-29@hotmail.com
}

Received: September 5, 2020 Accepted: October 10, 2020 Published: October 19, 2020

doi:10.5296/ijl.v12i5.17851

URL: https://doi.org/10.5296/ijl.v12i5.17851

\begin{abstract}
The current study aims to investigate the influence of interlingual and intralingual interference as sources of the errors of past and perfect tenses. The former refers to the errors generated by the negative effect of EFL learners' mother tongue as they try to bridge certain linguistic gabs. The latter, however, is pertaining to the errors produced by the target language itself as learners progressed in the learning process and face difficulties to employ the large amount of knowledge they have just acquired. The participants chosen are EFL Saudi Undergraduates whose academic specialisation is English. The result of the study showed that there was statistically significant difference between intralingual interference strategy and first language negative transfer as sources of errors of the past and present perfect tenses. This result revealed that the participants have reached a linguistic stage where the diverse rules of the target language itself create confusion for learners. The intralingual interference led the participants to making errors in the simple past, the past progressive, and the past perfect far more than when using L1 negative transfer strategy. While the first language negative transfer led the participants to committing errors in the present perfect progressive tense more so than when using the intralingual interference strategy. This result simply indicated that the difference in timeframe between Arabic and English led to significant number of errors which the students often transfer from their native language.
\end{abstract}

Keywords: L1 transfer, Interalingual interference, Tenses, Errors, Strategy 


\section{Introduction}

Several researchers have studied the errors made by language learners, due to the interlingual and intralingual interference of second language (SL) acquisition. This paper focused on two strategies as sources of common errors related to the use of past and present perfect tenses in English, specifically, first language (L1) transfer, and intralingual interference. Both interlingual and intralingual interference form very important aspects in second language (SL) research, particularly in the error analysis (EA) field. Interlingual interference concerns the errors resulting from the native language structure for second language learners (L2). Intralingual interference refers to the errors learners make due to their knowledge of the target, or second language (Corder, 1967; Gass, 1979; Larsen-Freeman \& Long, 1991; Selinker \& Gass, 2008). Four verb tenses were examined in this research, namely simple past, past continuous, past perfect, and present perfect progressive.

This study also detected the most frequent errors made with verb tenses related to the past and present perfect tenses due to L1 interference, and intralingual interference. Since L1 transfer and intralingual interference strategies stem from linguistic immaturity. It results in several types of errors, such as covert errors, which appear to be correct at the superficial level of a sentence, but they could be inappropriate or hard to understand within the overall context of communication. The other types of errors are referred to as overt errors, which are easy to recognise since they appear at the superficial sentence level. This is done through omission or addition of linguistic items, misordering by replacing one or more morphemes to another, or by changing the structure, which may lead to misformation errors (Corder, 1971; Dulay et al., 1982; Brown, 2000; Ellis, 1994). This study reviewed previous studies and research related to errors of past and present perfect tenses in English made by Arabic learners of English as a foreign language (EFL). In addition, this study examined the importance of error analysis (EA), including its definition and value, since EA is beneficial to L2 learners, researchers, and teachers (López 2009; Latto, 1983). The current study focused on the errors of the past and present perfect tenses produced by EFL Saudi Undergraduates using the L1 transfer and intralingual interference strategies.

\section{Literature Review}

\subsection{Definition of Errors}

Due to the nature of this study as it concentrates on errors, a salient definition of errors should be produced. Errors produced by L2 learners have been defined by a number of L2 researchers. For example, Ellis defined errors as 'the deviation from the norms of the target language' (1994, p. 51). As a result, errors form an inconsistency with the norms of the language being learned and are regarded as a violation of the target language's norms. For example, omitting the past morphemes' such as 'ed' is regarded to be a violation of the regular past rule in English. This definition is underpinned by Tenfjord et al. (2006), who suggested that errors could be considered as 'language usage deviating in definable ways from the way native speakers use the target language' (p. 102). When the L2 deviates from native speakers' usage, this production or utterance of language would be incorrect. Lee (2005) has defined a native speaker as a 'competent language user' (p. 10). Whilst Cook 
(1999) went further and suggested that people's first acquired language makes them a native speaker; other characteristics are incidental to describing how people use language. Hence, people who did not learn a particular language during their early childhood are not considered to be native speakers of that language.

Therefore, when language practice contradicts native speakers' standard usage, it is regarded as an error. Errors also occur as the by-product of L2 learners' attempts to express their spoken or written discourse with an insufficient understanding of the target language's system (Corder, 1981; Abdulsata, 2000). Correspondingly, Jabeen et al. (2015) defined errors as the result of deficient learning or linguistic inadequacy of the learners, and errors consist of mistakes that cannot be self-corrected. Moreover, Selinker and Gass (2008) stated that errors could be defined as 'red flags', which expose weak linguistic areas for L2 learners. Thus, errors deviate from the rules of the target language, and learners are unaware of the errors.

\subsection{Types of Errors}

First of all, L2 researchers make distinction between local and global errors and other researchers have divided errors into two types: overt and covert. With regard to local and global errors, Touchie (1986), quoting from Burt and Kiparsky (1974), argued that there was a distinction between these two types of errors. The former referred to the errors that do not retard understanding the meaning of utterances or effective communication. While global errors are considered to be more serious because these errors interfere with understanding, and they may hinder communication. Local errors involve noun, verb inflections, and the use of articles. Global errors, for example, consistently involve incorrect word order in a sentence.

On the other hand, concerning the overt and covert errors, Ellis (1994) stated that overt errors are easy to identify because they occur at the superficial level of the sentence: for example, *he runned quickly. According to Delay et al. (1982) overt errors are divided into four categories: omission, addition, misordering, and misformation. First, errors related to omission are characterized by the absence of linguistic items that should exist, such as *my friend arrives yesterday. Here, the morpheme '-ed' was omitted (morpheme could be a small grammatical unit, such as 'ed' for the past and it could be a full word as verb or noun). Second, addition errors refer to adding a linguistic item that should not be in the utterance for instance, he is goes to school every day (addition of the morpheme '-is'). These errors occur often at later stages of foreign language learning when L2 learners know more rules of the target language: Third, misformation errors are characterized by the change of structure or morpheme such as *he were a good student (were instead of was). Fourth, misordering errors occur with the wrong placement of one or a set of morphemes; for example, *she is all the time playing (Aboud, 2009). However, covert errors are well-formed at the superficial level of the sentence, but they do not mean what the learner intended to say, for example *he worked in this firm for three months so far (the simple past instead of the present perfect progressive). Covert errors tend to sound inappropriate in context, and they could be difficult to understand. Further, if the error does not contain an omission, addition, misformation, or misordering aspects, it should be defined as a covert error (Corder, 1971; Delay et al.1982; 
Ellis, 1994; Brown, 2000). This study focuses on covert and overt errors since they appear to be more appropriate for classifying tense errors.

\subsection{Error Analysis Theory}

The current paper concerns Error analysis (EA) of the past and present perfect tenses, so EA theory should be introduced including its definition and value. EA began to appear widely in linguistic study after the term was coined by the applied linguist Corder (1967), who is considered the father of error analysis. Errors made by L2 learners are inevitable, and these errors are significant features for L2 learners, not only researchers; because without committing errors, linguistic development cannot occur. EA comprises the linguistic analysis used in this research, which describes the typical errors that L2 learners commit. (Corder, 1967; Lennon, 2008). Indeed, López (2009) asserted that EA is crucial within SLA since it examines and observes the actual output (output concerns L2 learners' linguistic production) of L2 learners, which gives SL researchers the opportunity to describe how the language learning process develops, and teachers can identify L2 learners' errors to remediate them. In this sense, EA enriches L2 learners, teachers, and researchers (Shanks, 2005).

Thus, EA benefits L2 teachers, researchers, and learners, by offering the errors as evidence for the mechanisms that L2 learners follow in acquiring another language. As Selinker and Gass (2008) went further and pointed out that EA reflected the actual level of second language (L2) learners' knowledge. EA has contributed to the field of second language acquisition by quantifying L2 learners' errors, which assists both teachers and learners (Ellis, 1997). Further, the value of EA has been illustrated by a number of SL researchers. López (2009) suggested that by analyzing L2 learner's errors, information can be obtained about the quality of learning a second language.

EA also bestows several benefits on teaching, which may contribute to resolving particular linguistic difficulties. Teachers can highlight common mistakes that L2 learners experience and teach L2 learners to avoid them. Additionally, EFL teachers may need to offer EFL learners the approach of explicit teaching, in which teachers give formal instructions directly to learners, especially when teaching adults, since they have the ability to analyze and reflect upon grammatical aspects. Thus, adult L2 learners are aware of many metalinguistic features, such as how and why particular rules are applied in various linguistic contexts (Shank, 2005; Agulló, 2006; Ellis \& Shintani, 2014).

These metalinguistic teaching values are underpinned by Lott (1983), who suggested that the value of EA lay in giving L2 teachers techniques to analyse their students' errors, in addition to recognising the sources or causes of these errors. EA has provided EFL teachers with the errors that most commonly need to be highlighted. Similarly, Erdoğan (2005) suggested that EA can follow student progress, which enabled language teachers to keep the classes' studies flexible, according to L2 learners' needs, to realise which teaching strategies to employ, improve, or reconstruct. Thus, EA offers several benefits to EFL teachers by using focused teaching to solve the specific linguistic problems that L2 learners face. 


\subsection{Sources of Errors}

This research focused on both interlingual interference, and intralingual interference as sources of errors of the past and present perfect tenses. L1 transfer is commonly acknowledged among L2 researchers as a primary source of language errors. Gass (1984) pointed out that in the last few decades, there has been a revival of interest in language interference as one of the mentalist mechanisms that underlie SLA. First language transfer 'refers to the incorporation of L1 into the knowledge systems of the L2, which the learner is trying to build' (Ellis, 1994, p. 28). L1 transfer is considered to have an essential mentalist process in L2 learning. Al-Khawalda, and Alhaisoni (2012) have suggested that the L1 transfer referred to generalizing or applying of the learner's knowledge about their L1 language to assist them in using and comprehending the L2. For instance, EFL Arabic learners are more likely to use the simple present instead of the present perfect progressive due to the difference between the two languages, as Arabic does not have the present perfect progressive tense (Zihiri, 2010).

Intralingual interference, on the other hand, concerns errors that occur due to the interference within the rules of the language being learned (the target language) without a relationship to the first language. This would comprise incorrect choices of tenses, addition errors (adding linguistic items that are not required) and omission errors (omitting linguistic items that are necessary to exist). (Corder, 1967; Gass, 1979; Larsen-Freeman \& Long, 1991; Selinker \& Gass, 2008; Abi Samra, 2003; Adam; 2012). For example, when EFL Arabic learners also commit errors due to the rules of the target language itself, they may choose inappropriate tenses such as *he was working now instead of he is working now, because of the confusion between the rules of the target language itself (Khazaal, 2009).

Khazaal (2009) stressed that intralingual interference was as significant a cause of L2 errors as L1 interference. Mahmoud (2014) also stated that L2 learners utilised both interlingual and intralingual strategies to facilitate target language learning. Heydari and Bagheri (2012) stated that interlingual errors involved types of errors affected by the L1 that interfered with target language learning. However, intralingual errors include types of errors initiated by target language interference. The key difference between interlingual and intralingual errors are that the former concerns similar errors in structure to a semantically equivalent utterance in the learners' first language. However, intralingual errors reflect the mental mechanisms that underlies the learner's language development, which is often in accordance with the nature of strategies used by children when learning their first language (R. Jiménez Catalán 1993; Dulay, Burt \& Kraslien 1982).

\subsection{Background Research of English Errors of Past and Present Perfect Tenses Made by EFL Arabic Learners in Written Discourse}

Initially, this paper focused primarily on the errors of past and present perfect tenses in English made by EFL Arabic learners. This study focused on four tenses, the simple past, the past progressive, the past perfect, and the present perfect progressive. In fact, there have been a few EA studies that focused on the past and present perfect tenses made by EFL Arabic learners, especially, the present perfect progressive tense. 
For several decades, a number of studies have been conducted concerning errors of English verb tenses committed by Arabic learners. Al-Buainain (2011) designed a study of EFL Arabic learners' errors in writing and found that there is a misunderstanding of time frame of the English language by Arabic speakers. In addition, EFL Arabic learners sometimes misuse the present perfect tenses.

Expanding on this, Zhiri (2014) studied tenses errors made by EFL Arabic learners and found that a number of students appeared to be unable to translate the present perfect progressive. The present perfect progressive tense seemed to be problematic, because it provided $20 \%$ of the total errors. Zhiri concluded that EFL Arabic learners find it difficult to combine the present perfect into progressive tenses or to use the perfective aspects to produce the present perfect progressive tense. Significantly, they overused the simple present instead.

Moreover, Abu-Joudeh et al. (2013) investigated errors made by Jordanian undergraduates whose academic specialisation was in the English language. The study aimed to examine the uses of the perfect verbs of the English language by Jordanian English-major undergraduates. The students were given a translation task to achieve the objectives of this study. The results of this study showed that the participants were unable to translate the equivalent Arabic bare perfect sentences into English perfect forms. Although the Arabic sentences involved particles as signs to determine the equivalent tense, for example, the particle 'kuntu qad' in Arabic ('kuntu' is translated as 'was' in English and sometimes it is accompanied by the function word qad ) is often used when translating the past perfect into English to help determine the equivalent tense. They translated primarily into the simple past, form instead of the perfect forms. This emerged as a common problem that EFL Arabic speakers face, which consisted of rendering the appropriate tenses during translation, particularly the correct use of perfect forms in the English language. Likewise, Obeidat (2014) conducted an EA study about the uses of the past perfect by EFL Arabic learners. The study involved translation tasks from Arabic into English. The result of the study revealed that EFL Arabic learners used the simple past instead of the past perfect due to the differences between Arabic and English.

\section{Research Design}

\subsection{The Aims of the Current Study}

To date, there has not been an EA study on EFL Arabic learners, obviously inclusive of EFL Saudi undergraduates including L1 transfer strategy and the intralingual interference strategy, as the sources of errors in employing the past and present perfect tenses. The current study investigated the influence of the L1 transfer and the intralingual interference strategies as sources of errors. In this study, the research conducted aims to demonstrate that EFL Saudi Undergraduates confront difficulties when employing the past and present perfect tenses correctly due to the fact that Arabic has fewer tenses than English, particularly, the perfect and imperfect tenses. The students may omit linguistic items due to the L1 negative transfer such as 'ing' in the case of the past progressive.

It was hypothesized that if the tense did not have an equivalent tense in Arabic, for example, the perfect tenses and constructing the past progressive, then the hypothesis was that the 
students would bridge this linguistic gap using the negative transfer from their mother tongue because of the differences between the two languages. Therefore, they could use the simple past instead of the past perfect, and they could use the simple present instead of the present perfect progressive, and was/were with the imperfect form to construct the past progressive.

On the other hand, since English has several rules with tenses including the rules of the past and present perfect tenses, it is hoped that EFL Saudi Undergraduates could simplify the past and present perfect tenses in association with the intralingual interference, meaning within the target language itself since they have gained and made progress in their knowledge of English. For instance, using the simple past instead of the past progressive, omitting 'ed' in the case of the simple past. So, the participants could confuse between the different rules of the target language, which compel them to use the past and present perfect tenses in incorrect contexts.

\subsection{Research Questions}

- How often do EFL Saudi undergraduates make L1 negative transfer errors related to the past and present perfect tenses compared with intralingual transfer?

- What are the types of tenses errors caused by both L1 negative transfer and intralingual interference and how many errors made for each tense produced by both strategies?

- What is the most erroneous tense that obtains the most frequent errors in comparison with the other tenses?

- How the tenses errors are made by EFL Saudi undergraduates under the influence of both L1 negative transfer and intralingual interference?

\subsection{Participants Research}

The study involved 48 undergraduate students whose academic specialization was the English language, and all participants were aged between 20-25 years. All the subjects were males and were selected randomly from the English department at King Khalid University. The participants are seventh and eighth levels or in the fourth year. The ethical approval was issued prior to collecting the data. The English department at King Khalid University was initially addressed formally to inform the students about their participation in the study. All students participated voluntarily and were informed that they could withdraw from the study at any time. In addition, all of the students had been studying English as foreign language for at least 7 years as a compulsory subject at school, then specializing in English as their academic course at the university. The tasks given to the participants were a free translation task from Arabic into English.

\subsection{Instruments and Procedures}

The participants were asked to translate 12 Arabic sentences into English and were provided with the link to the study, since the study was online. The sentences were in standard Arabic. Standard Arabic is considered to be the formal language used in education in Saudi Arabia. The study involved four verb tenses related to the past and present perfect tenses in English; 
specifically, the simple past, past progressive, past perfect, and present perfect progressive tenses.

Each sentence in the translation task included one tense or in some cases two tenses come in one sentence, such as one sentence that contains both the simple past and the past perfect tenses. The distribution of sentences for each tense was not in a sequential order. In other words, the first sentence involved the simple past accompanied by the past perfect, but the second sentence included the present perfect progressive, so the tenses were distributed randomly. Therefore, the four tenses were distributed equally in terms of number. The Arabic sentences were translated to be equivalent into English tenses. For example, the present perfect progressive was provided within and appropriate context that indicated that the result of the action had not yet finished in order to let the students determine the present perfect progressive tense (see Appendix A for all sentences with their translations).

\subsection{Data Analysis}

According to Corder (1981) there are four steps that should be carried out when performing EA: collection of language learners' samples, identification of errors, description of errors, and explanation of errors (Garrido, 2012). Accordingly, the first step was the collection of L2 learners' errors, followed by an identification of the errors.

With regard to identifying errors, Corder (1981) suggested that it is important to compare the erroneous utterances with what the learner ought to have said. There should be a comparison between the original utterances and the reconstructed utterances (of the target language); the correct utterances that possess the meaning intended by the L2 learner. The reconstructed utterances could be considered as translations of the learners' utterances into the target language.

Further, as this study included both quantitative and qualitative methods. Firstly, since the purpose of the study was to identify the influence of both L1 negative transfer and intralingual interference strategies errors, so the quantitative method was used to count errors to know which strategy was more influential in the creation of errors (there were a small number of ambiguous errors and they were excluded from the study). Since the Chi-square test is used with frequencies of errors, accordingly, this test was used to calculate the frequencies of errors stemming from the L1 negative transfer and intralingual interference to achieve the objectives of the study. For example, identifying whether there is a significant difference between the L1 transfer errors and the intralingual interference strategies errors. The qualitative method was employed to account for and explain in further detail how certain errors occurred, particularly the errors that appear to be of interest.

\subsection{Identification and Classification of Errors}

To identify the errors, the current study excluded the correspondent sentences to native speakers and the norms of the target language. Only the erroneous utterances related to the four tenses (past perfect, past progressive, simple past, and present perfect progressive) were counted. The erroneous tenses were compared in both English and Arabic to identify whether the error was made due to the L1 negative transfer (Arabic) or due to the intralingual 
interference (English). The erroneous tense, which corresponded to the Arabic tense or structure, was counted as an error made due to the negative L1 transfer. Similarly, the erroneous tense, which is in accordance with the rules of the target language (English) was counted as an error made because of intralingual interference strategy. Moreover, the errors were classified into categories to describe them. With regard to error classification, this study is similar to Garrido's (2012), where errors were classified into covert and overt. The covert errors do not have subcategories, whereas overt errors have four categories: specifically, addition, omission, misformation, and misordering.

\subsection{Explanation of Errors}

Ultimately, learners' errors were explained according to interlingual and intralingual interference. As previously mentioned, interlingual interference is led by the negative influence of the L2 learners' native language (Arabic). However, it is notable that intralingual interference concerns the confusion or interference between the rules of the target language itself (English), which forces L2 learners to use a range of strategies to facilitate the process of learning. Thus, interlingual errors will be explained by the negative influence of L1 transfer strategies, such as omission, addition, misordering, and incorrect choices of tense. However, the intralingual errors will be explained due to the influence of intralingual interference as it involves a set of factors, incorrect choice of tenses through choosing simpler linguistic structures, omission, addition, incomplete rule application, and overusing or extending the application of certain rules of the target language.

\section{Results and Discussion}

\subsection{Quantitative Analysis}

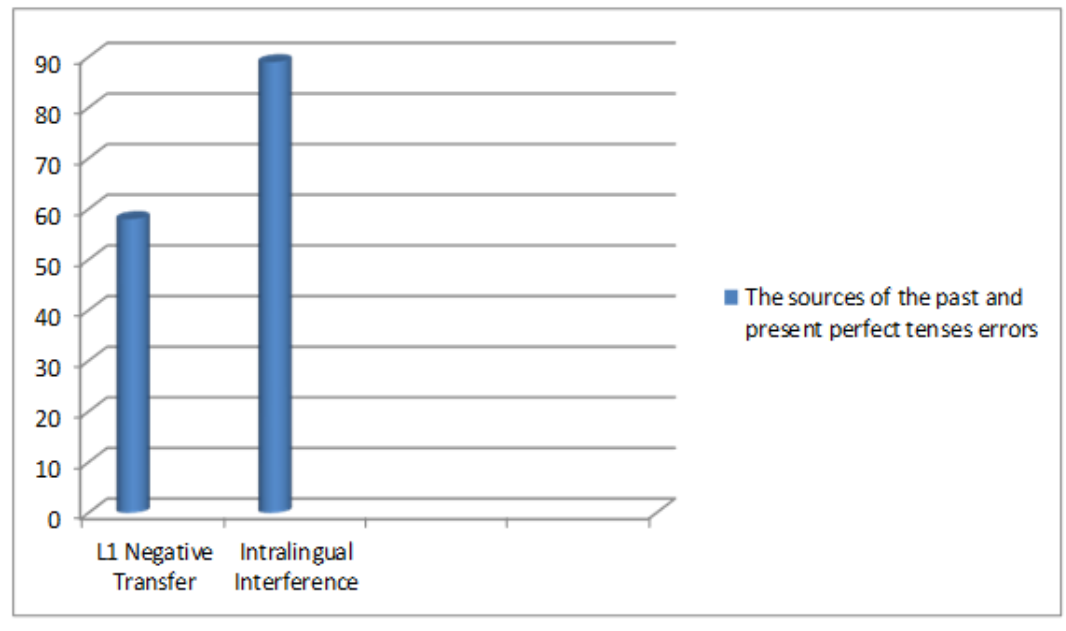

Figure 1. The total number of errors made due to the L1 transfer and the intralingual interference strategies

One purpose of this paper is to compare the influence of L1 transfer and intralingual interference strategies as sources of errors of past and present perfect tenses. The first research question asked which of the two strategies - the L1 negative transfer strategy or the intralingual interference strategy - generates more errors. As shown in Figure 1, the observed data of the total number of errors for the L1 transfer strategy errors (58) are less than those 


\section{Macrothink}

International Journal of Linguistics

ISSN 1948-5425

2020, Vol. 12, No. 5

for the intralingual interference strategy (89). The results of the chi-square test showed that the number of errors made between the L1 transfer and the intralingual interference is statistically significant $(\mathrm{X} 2=6.54 ; \mathrm{df}=1 ; \mathrm{p}<0.05)$. Accordingly, there is a significant difference between the L1 transfer and intralingual interference strategies in generating errors related to the past and present perfect tenses. This interpretation indicates that the students rely on the intralingual interference strategy within the target language far greater than L1 transfer strategy.

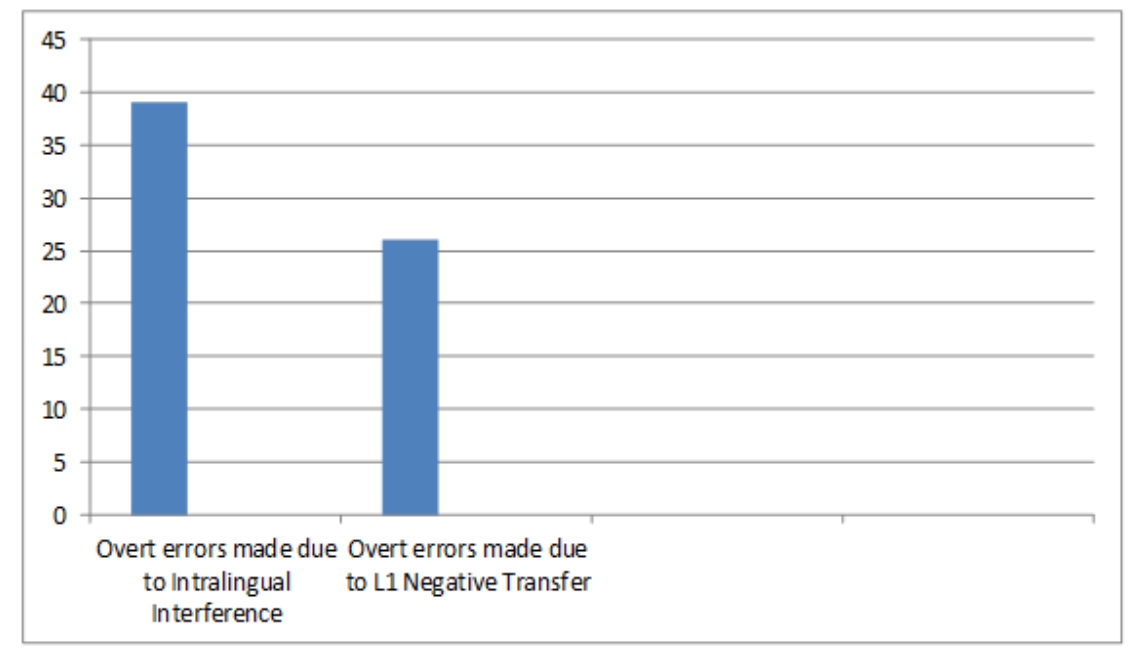

Figure 2. The total number of overt errors of the L1 transfer and the intralingual interference strategies

The second research question was raised to identify the errors produced by the L1 transfer and intralingual interference strategies. The types of errors that result from the L1 negative transfer and intralingual interference strategies: specifically the number of overt or covert errors. Figure 2 shows the actual number of overt errors produced by the L1 transfer strategy as 26, whereas the number of overt errors generated by the intralingual interference strategy was 39. First, the comparison must be made between the total number of overt errors produced by the L1 transfer strategy and the intralingual interference strategy. The chi-square test shows that there was no statistically significant difference between the L1 transfer and intralingual interference strategies, according to the number of overt errors $(\mathrm{X} 2=2.6 ; \mathrm{df}=1$; $p>0.05)$. Thus, it is proposed that the chi-square test shows that the overt errors are more likely to be made approximately half of the time due to the L1 transfer strategy and half of the time because of the intralingual interference strategy. 


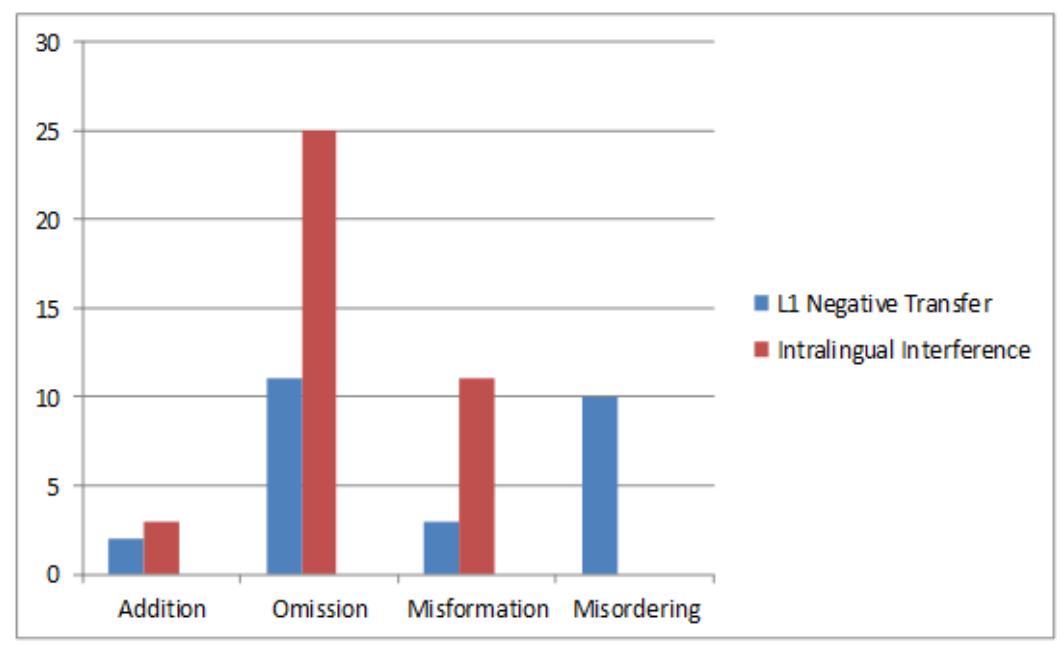

Figure 3. The total number for each type of overt errors made due to the L1 transfer and intralingual interference strategies (except misordering errors, since they were produced only by the strategy of L1 transfer)

Following the second research question, the subcategories of the overt errors of the L1 negative transfer and intralingual interference strategies need to be compared with each other. Figure 3 shows the overt errors for the L1 transfer and intralingual interference strategies. Overall, the intralingual interference strategy generated more errors in three types of overt errors, namely addition, omission, and misformation than the L1 transfer strategy. However, misordering errors have been excluded from the comparison since they were generated by the L1 transfer strategy only.

The chi-square test statistically reveals the differences between the subcategories of the overt errors resulted from the $\mathrm{L} 1$ transfer and the intralingual interference strategies. The chi-square test displays that there is no statistical differences between the L1 transfer and the intralingual interference strategies in addition errors $(\mathrm{X} 2=0.2 ; \mathrm{df}=1 ; \mathrm{p}>0.05)$. However, the chi-square test exhibited that there is a significant statistical difference between the L1 transfer and intralingual interference strategies in omission errors $(\mathrm{X} 2=5.4 \mathrm{df}=1 ; \mathrm{p}<0.05)$. Similarly, the results of the chi-square test show that the difference between L1 transfer and intralingual interference within misformation errors was statistically significant $(\mathrm{X} 2=4.57$; $\mathrm{df}=1 ; \mathrm{p}<$ 0.05). It is suggested that the chi-square test shows that the addition errors are likely to be made by the L1 transfer and intralingual interference strategies in almost equal measure, whereas the omission and misformation errors are significantly more likely to be committed due to the intralingual interference strategy. This indicates that the students are more likely to make misformation and omission errors due to the intralingual interference strategy compared with the L1 transfer strategy. 


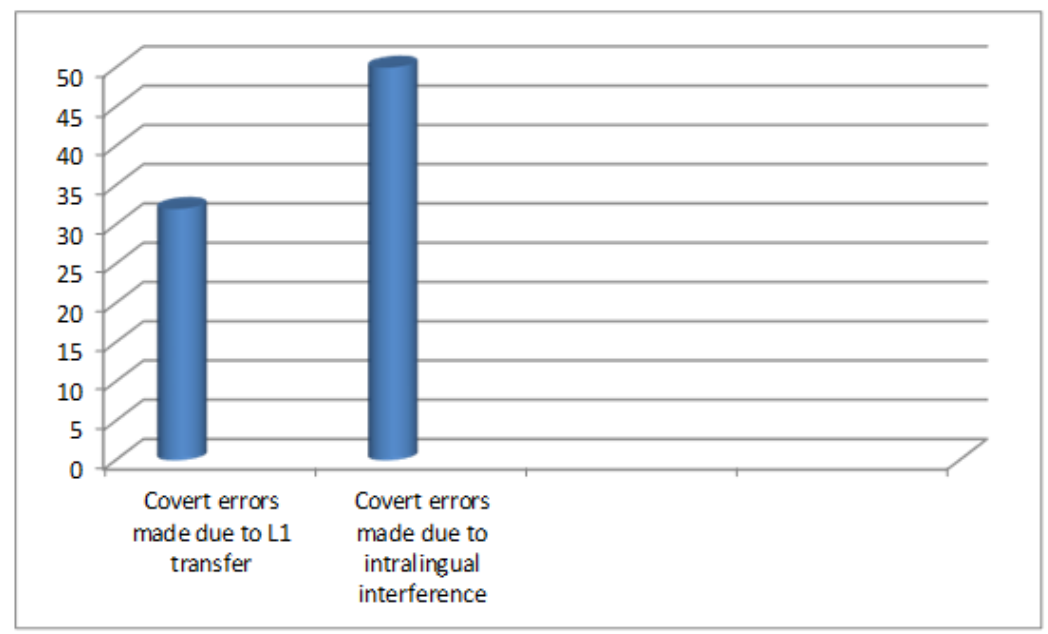

Figure 4. The total number of covert errors of the L1 negative transfer and the intralingual interference strategies

Moreover, the second research question was raised to examine the types of errors that result from the L1 transfer and the intralingual interference strategies; focusing on covert errors. Figure 4 shows the actual number of covert errors produced by the L1 transfer strategy, which was 32, whereas the number of covert errors generated by the intralingual interference strategy was 50. The results of the chi-square test demonstrated that there is statistically significant difference between the L1 transfer and the intralingual interference strategies concerning covert errors $(\mathrm{X} 2=3.95 ; \mathrm{df}=1 ; \mathrm{p}<0.05)$. As a result, the chi-square test showed that covert errors are more likely to be committed by intralingual interference strategy in comparison with L1 negative transfer.

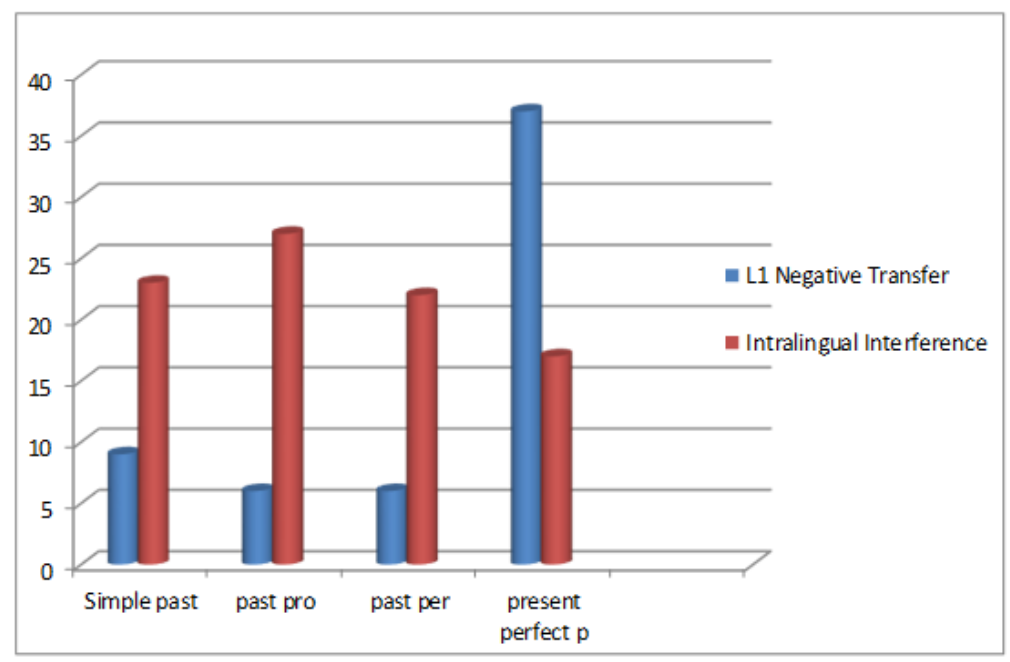

Figure 5. The total number of errors for all tenses made due to the L1 transfer and the intralingual interference strategies

Furthermore, the last point in the second research question was posed to identify the most erroneous tenses that result from the L1 transfer and the intralingual interference strategies. Figure 5 shows the actual number of errors made using tenses due to the L1 transfer and 
intralingual interference strategies, and it illustrates that the intralingual interference strategy generated far more errors than the L1 transfer strategy in the simple past, the past progressive, and the past perfect tenses. On the other hand, the L1 transfer strategy produced more errors than the intralingual interference strategy when using the present perfect progressive tense.

The chi-square test calculated the differences between the L1 and intralingual interference strategies for the tenses errors. First of all, the results of the chi-square test demonstrated that there was a statistically significant difference between the L1 transfer and intralingual interference strategies within the errors made using the simple past tense $(\mathrm{X} 2=5.12 ; \mathrm{df}=1$; $\mathrm{p}<0.05)$. Similarly, the results of the chi-square test demonstrated that there was a statistically significant difference between the L1 transfer and intralingual interference strategies within the errors using the past progressive tense $(\mathrm{X} 2=13.36$; $\mathrm{df}=1 ; \mathrm{p}<0.05)$. The third tense was the past perfect, and the results of the chi-square test demonstrated that here too there was an obvious numerical significant difference between the L1 transfer and the intralingual interference strategies within the errors of the past perfect tense $(\mathrm{X} 2=9.14$; df $=1 ; \mathrm{p}<0.05)$.

Ultimately, for the present perfect progressive tense, the results of the chi-square test demonstrated that there was statistically significant difference between the L1 transfer and intralingual interference strategies within the errors of the present perfect progressive tense $(\mathrm{X} 2=7.40 ; \mathrm{df}=1 ; \mathrm{p}<0.05)$. As a result, the chi-square test shows that the errors of the simple past, the past progressive, and the past perfect were more likely to be made by employing the intralingual interference strategy than the L1 transfer. On the other hand, the chi-square test shows that the errors of the present perfect progressive tense were more likely to be committed due to L1 negative transfer than intralingual interference.

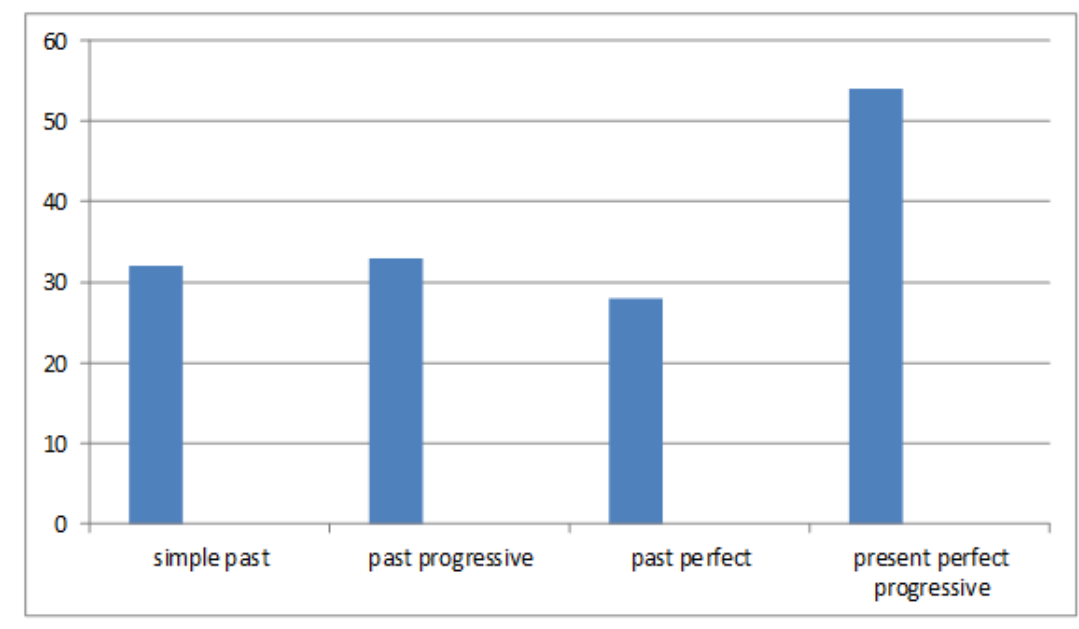

Figure 6. The total number of errors for all tenses made due to the L1 transfer and the intralingual interference strategies

Figure 6 demonstrates the total number of errors for the past and present perfect tenses. The third research question purported to determine the tense with the most frequent errors compared with the other tenses. Since the present perfect progressive has the highest number of errors (54) as Figure 6 shows, it was compared with the other tenses. Initially, the 
chi-square test demonstrated that the difference between the present perfect progressive and the past perfect was statistically significant $(\mathrm{X} 2=8.24$; $\mathrm{df}=1 ; \mathrm{p}<0.05)$. In addition, the chi-square values between the present perfect progressive and simple past tenses were statistically significant $(\mathrm{X} 2=5.62 ; \mathrm{df}=1 ; \mathrm{p}<0.05)$, along with the difference between the present perfect progressive and the past progressive tenses $(\mathrm{X} 2=5.06$; $\mathrm{df}=1 ; \mathrm{p}<0.05)$. Therefore, the chi-square test revealed that the error count of the present perfect progressive compared with the other tenses were statistically greater. Thus, the present perfect progressive was perceived to be the most challenging and difficult tense for EFL Saudi undergraduates to employ properly when compared with the other tenses.

\subsection{Qualitative Analysis}

The fourth research question is raised to identify how the errors pertaining to the past and present perfect tenses are made owing to interlingual and intralingual interference. The following analysis comprises the nature of mistakes for each tense and whether they are committed due to L1 transfer or intralingual interference:

\subsubsection{Present Perfect Progressive Tense $\left(1^{*}\right)$}

The examples below (Example 1.1 - A. B.) are errors that the participants have made with the present perfect progressive.

Example 1.1

A. Nahnu natadarbu fi sharikiti alnift munthu isboain (Arabic)

Train we at company oil for two weeks (Arabic).

- We train at the oil company for two weeks (L1 transfer error).

B. - I was looking for my car keys since yesterday morning (the intralingual interference error).

The first example that can be addressed regarding errors of the present perfect progressive is example 1.1.A. The result of the present perfect progressive shows the direct influence of the L1 (Arabic) on the target language (English). Students tend to use the present perfect progressive in the similar tense in Arabic, which is equivalent to the simple present in English as example 1. A illustrates.

Further, the second example that needs to be explained is example 1.1.B shows. The participants simplified the present perfect progressive tense by using the past progressive tense. As example 1.1. B shows that the student was affected by another rule within the target language. The present perfect progressive was expressed by the past progressive. They simplified the present perfect progressive by choosing simpler tense that they know under the influence of the intralingual interference. This could be attributed to the complexity of the present perfect progressive, in addition to the deficiency of knowledge of the target language.

$\left(1^{*}\right)$ The present perfect progressive tense is used to refer to something happened in the past and still going on at the present (Swan, 1992). 


\subsubsection{Past Progressive Tense $(2 *)$}

The examples below (2.1A.B.C) are errors that the participants have made with the past progressive.

\section{Example 2.1}

A. - we was played basketball yesterday at 3 p.m. (the intralingual interference error).

Albariha enda assaa 10 kuntu aushahidu almubarat ala attilfaz (Arabic)

B. Night last was I watch the match on the T.V (Arabic)

- I was watch the TV last night at 10 p.m. (L1 transfer error).

C. - what do you do last night at 10 p.m. (the intralingual interference error)

The first example on the errors of the past progressive is example 1.2.A. The past progressive tense includes various errors, specifically, misformation errors. Interestingly, the past progressive was misused by altering its form. That is to say, the participants substituted or exchanged the past tense marker of the plural "were" with "was". In addition, '-ing' for the past progressive indicator was replaced by '-ed' as in example 1.2.A. So, by forming and constructing the past progressive under the effect of other rules in English led to the malformation of the past progressive sentence.

On the other hand, the second example of the past progressive errors is example 1.2.B. This Example shows the L1 transfer negative influence that led EFL Saudi undergraduates to make past progressive tense errors. In other words, the students conveyed the structure of Arabic when forming the past tense progressive. The past progressive is constructed in Arabic by was/were as well as the main verb, which does not undergo any additions. Hence, the students dropped the past progressive morpheme "-ing" due to the difference between Arabic and English languages in constructing past progressive sentences. Further, the third example of the past progressive errors is 1.2.C. The subjects simplified the past progressive tense by substitution of simple present tense as example 1.2.C shows. This indicates that the participants confused between the rules of the target language itself.

(2*) The past progressive tense is used to refer to something was in progress at some point during the past: for example, what was my son doing at 10 yesterday morning? (Swan, 1992).

\subsubsection{Past Perfect Tense ( $\left.3^{*}\right)$}

The examples below (3.A.B.C) are errors that the participants have made with the past perfect.

Example 1.3
A. - When my wife started to prepare the dinner, the match has begun (the intralingual interference error)

B. Endma wasala abi kanat ummi qad hatharat wajbah lathithah lahu (Arabic) 
When arrived father my was mother my prepared meal delicious for him (Arabic)

- When my father arrived, was my mother had prepared meal for him (L1 transfer error)

The first example of the past perfect errors is 1.3.A. The results show that the participants tended to simplify the past perfect tense into the present perfect tense. Interestingly, the students made errors in the past perfect by substituting the present perfect as example 1.3. A illustrates. Although there were past perfect particles in Arabic, namely "kanat qad", which is equivalent to the past perfect in English's 'had' plus past participle. However, the students chose the present perfect instead as example 13.A shows. The large number of the incorrect choices of tenses made by the participants indicated the influential role of intralingual interference. The second instance of the past perfect errors is example 1.3.B, The students made addition errors by transferring the particle "kuntu" into its English equivalent, which is 'was' as example 1.3. B demonstrates.

Consequently, it could be seen that the participants tried to simplify the past perfect by choosing other tenses under the effect of intralingual interference. In fact, most of the errors made with the past perfect tense belong to the intralingual interference strategy, in particular covert errors, which refer to the effective role of the intralingual interference. EFL undergraduates add linguistic aspects, which are not required, using knowledge of their native language as example 1.3.B illustrates.

(3*)The past perfect tense refers to 'the earlier past, p.397' or to the first action that happened during a time in the past. For instance, when I arrived at the library, my friend had already gone (Swan, 1992).

\subsection{The Impact of L1 Negative Transfer and Intralingual Interference as Sources of Tenses Errors}

Both the L1 negative transfer and the intralingual transfer constituted an obstacle for EFL Saudi undergraduates. However, it would be evident that intralingual transfer was more challenging where they confused among English language rules (the target language) far more as opposed to the errors that associated with L1 transfer. In other words, a large number of the past and present perfect tenses errors stem from the reciprocal interference of the target language rules. This study also could partially support Nabil's finding (2007) who investigated tenses errors produced by EFL Arabic learners and asserted that the interlingual is as significant as intralingual interference as sources of tenses errors.

In fact, as the mistakes caused by the intralingual interference are greater than those made because of the L1 transfer revealed that the EFL Saudi undergraduates have reached a certain linguistic stage, where they have made a noticeable progress towards the language being learned (English). Nevertheless, the results demonstrated that both Arabic and English affect the students' errors related to the past and present perfect tenses, and EFL Saudi undergraduates are influenced by both the L1 negative transfer and the intralingual interference strategies. The students used L1 strategies when they faced tenses that do not exist in their native language. They filled in this linguistic gap using negative transfer from their mother tongue. For example, students formed the present perfect progressive tense as 
simple present, meaning the present perfect progressive is used as simple present in Arabic. Additionally, students used the L1 negative transfer and the intralingual interference strategies that resulted in overt errors, such as misformation errors.

Moreover, EFL Saudi undergraduates violated the timeframes of English by following the timeframe of their L1. This was made obvious from the students' present perfect progressive tenses usage. This is compatible with Zhiri's study (2014). In his research on investigating the use of the present perfect progressive by EFL Arabic undergraduates. Zhiri found that Arabic learners transfer the present perfect progressive into the simple present due to the negative transfer from their mother tongue. The result of the present perfect progressive in this paper is in line with Zhiri's. It seems that the present perfect progressive is challenging for EFL Arabic learners. Likewise, These findings were in line with Al-Buainain's (2011), who showed that EFL Arabic learners do not understand the timeframe of English language, which results in several errors when using and forming English verb tenses. In the current study, EFL Saudi Undergraduates applied knowledge from their mother tongue. That is to say, they dealt with the past and present perfect tenses due to their understanding of their L1 tenses uses.

The students in this study relied on the intralingual interference strategy when they confronted certain rules that appeared to be complicated. Therefore, they applied incomplete knowledge of the rules regarding tenses, which resulted in various types of errors, such as omission, addition, and misformation. Clearly, EFL Saudi undergraduates are driven by both their knowledge of their mother tongue, and the intralingual interference strategy, when using past and present perfect tenses. The misuse of tenses by EFL undergraduates in this study was supported by the study of Tushyeh (1996). Tushyeh found that EFL Arabic speakers misused verb forms in English due to the fact that Arabic has fewer tenses, such as the perfect and imperfect (past and non-past). However, English contains several tenses, for example, the present perfect progressive and the past perfect are not found in Arabic. This may be one main reason why EFL Arabic Undergraduates do not employ the English tenses correctly.

In the current research, EFL Saudi Undergraduates tended to choose the simple past in contexts where the past progressive should be utilised. So, they simplified the present perfect progressive tense by using the past progressive instead. Such results tend to reinforce Nabil's (2007) work, which found that EFL Arabic speakers avoided the complicated and difficult tenses by using simpler ones. He also asserted that intralingual interference is one major reason for that. The findings of Nabil has been asserted in the current paper, which might mean that EFL Arabic learners rely on the intralingual interference as a strategy to simplify the target language by using easier tenses.

\section{The Significance of the Study}

The findings of this research paper involve several benefits for the Saudi society generally, because English has become a compulsory module in several educational institutions in Saudi Arabia. The researcher carried out the current study since he has been teaching English as a foreign language for several years as he used to encounter frequent tenses mistakes by students. So, he intended to investigate this morph-syntactic problem profoundly so that 
learners would overcome tenses errors. The chosen tenses involve four English tenses, namely. Past perfect, past simple, past continuous, and present perfect progressive. The top priority is to identify the reasons beyond committing errors related to these four tenses. The study focuses exclusively on two sources, specifically the negative transfer from EFL learners' native language due the grammatical differences between the languages and the other cause is intralingual interference. Intralingual interference concerns with the errors caused by the target language itself. The results of this study will be beneficial greatly for EFL teachers, learners, and researchers.

EFL teachers are expected to shed light on the nature of mistakes in this research paper and their causes. This would enable them to eradicate most of the students' mistakes in the four tenses when choosing appropriate teaching approaches with tenses, which may enhance learners' knowledge and understanding enormously. Further, EFL learners tend to benefit from the outcomes of this research in avoiding their peers' errors and their dynamics such as L1 negative transfer. Therefore, they are more likely to be more attentive in using the four tenses that have been examined throughout this paper. Ultimately. L2 researchers would realize how EFL Saudi undergraduates adopt certain mentalist mechanisms to acquire the four tenses in educational settings where English is taught as a foreign language.

\section{Conclusion and Pedagogical Implications}

This study discovered that L1 negative transfer is less influential as a source of the past and present perfect tenses errors compared with the intralingual interference strategy that enforced EFL Saudi learners to produce the largest number of errors. L2 learners use L1 transfer and the intralingual interference strategies to facilitate the learning process of the target language, attempting to make it easier, simpler, and to reduce the linguistic burden (Takashima, 1992; Khazaal, 2009; Mahmoud, 2014). Specifically, the results of this study demonstrated that the present perfect progressive verb tense generated the most frequent errors. There is a significant difference between the formation of the present perfect progressive tense and the other tenses, which revealed the present perfect progressive tense to be the most challenging and difficult for EFL Saudi Arabian undergraduates.

The current study has shown that L1 transfer forms an obstacle in learning the present perfect progressive tense due to the increased difficulties in this tense. On the other hand, the intralingual interference is more likely to lead to errors related to the simple past, the past progressive, and the past perfect tense. The EFL Saudi Undergraduates confused between the past progressive and the simple past. This shows that the students have gained progress in the target language knowledge, which led them to confuse between the different rules of the language being learned (English). The errors produced due to the L1 transfer and the intralingual interference strategies illustrated the linguistic progress of EFL Saudi undergraduates, and their linguistic production reflected the linguistic stage of the students' development.

This study revealed actual values for EA, and reflected the actual level of L2 learners' linguistic progress (Selinker and Gass, 2008), by exposing EFL Arabic learners' internal constructs and the ways in which these learners facilitated the learning process, using L1 
transfer and the intralingual interference strategies (López, 2009).Thus, EA has raised awareness concerning problematic issues regarding the errors of the past and present perfect tenses in English by eliciting EFL learners' input. In fact, errors' inferences are seen very clearly in SL research. As a result of the findings in this study, L2 teachers need to employ appropriate and effective approaches when teaching verb tenses to EFL Arabic learners. For example, the tenses concerned with the present perfect progressive tense should be explained in the learners' native language, which is Arabic in this case (Al-Zoubi \& Abu-Eid, 2014). EFL teachers may need to be shown examples of errors, such as those demonstrated in this paper, so that they diagnose and treat them. In addition, EFL Arabic learners can take advantage of the errors highlighted in this paper to try to eradicate the errors and learn the correct uses shown within the current study.

Ultimately, the door remains open for SL researchers to investigate the errors of the past and present perfect verb tenses between intermediate and advanced L2 Arabic learners to see whether there are differences between the interlingual and intralingual interference, depending on the learners' L2 acquisition level. Also, an investigation of the past and present perfect tenses needs to be made based on the educational environment, in other words as to whether L2 learners were taught in an English speaking country or in an educational context where English is taught as a foreign language, as the current study has focused on EFL Arabic male Undergraduates studying English as a foreign language only.

\section{References}

Abdulsata, P. (2000). An Error Analysis of Srinakharinwirot University Second-Year English Major Students Compositions. Unpublished master's thesis, MA (English). Bangkok: Graduate School. Srinakharinwirot University. Thailand. Photocopied.

AbiSamra, N. (2003). An analysis of errors in Arabic speakers' English writings. Investigating writing problems among Palestinian students studying English as a foreign language. Unpublished doctoral dissertation.

Aboud, H. (2009). Error Analysis of the university level students in the use College of Education. Sammarra Tikrit University.

Abu-Joudeh, M., Asassfeh, S. M., Al-Shaboul, Y., \& Alshboul, S. (2013). Translating Arabic Perfect Verbs into English by Jordanian Undergraduates. Journal of Language and Literature, 4(2), 44-53. https://doi.org/10.7813/j11.2013/4-2/6

Adam, M., \& Taha, M. (2012). Morpho-syntactic errors of ESL learners' written essays: a Minimalist Approach. Doctoral dissertation, University of Malaya.

Agulló, G. L. (2006). Overcoming age-related differences. ELT Journal, 60(4), 365-373. https://doi.org/10.1093/elt/ccl027

Alahmadi, N. S. (2014). Errors Analysis: A Case Study of Saudi Learner's English Grammatical Speaking Errors. Arab World English Journal, 5(4).

Al-Badawi, K. (2012). An analysis of phonetic, morphological and syntactic errors in English: 
a case study of Saudi BA students at King Khalid University. International Journal of Social Science and Humanity, 2(6), 536. https://doi.org/10.7763/IJSSH.2012.V2.165

Al-Baldawi, W. N., \& Saidat, A. M. (2011). Linguistic overgeneralization: a case study. International Journal of Academic Research in Business and Social Sciences, 1, 184.

Al-Buainain, H. A. (2011). Researching Types and Causes of Errors in Arabic Speaker's Writing. QNRS Repository, 2011(1), 2571.

Alhawary, M. T. (2011). Modern standard Arabic grammar: a learner's guide. Location of Publisher: John Wiley \& Sons.

Ali, N. (2007). Some linguistic problems facing Arab learners of English. ADAB Alrafidayn, (48), 1-14.

Al-Khawalda, M., \& Alhaisoni, E. (2012). Linguistic transfer: Example from the usage of 'wish'by Arabic native speakers. ELT Research Journal, 1(1), 63-70.

Al-Oliemat, A., \& Al-Khawalda, M. (2007). Linguistic Transfer: Example from Arabic users of English. Mutah University-Jordan.

Al-Zoubi, D. M., \& Abu-Eid, M. A. (2014). The Influence of the First Language (Arabic) on Learning English as a Second Language in Jordanian Schools, and Its Relation to Educational Policy: Structural Errors. Sino-US English Teaching, 11(5), 355-372.

Barbour, S., \& Stevenson, P. (1990). Variation in German: A critical approach to German sociolinguistics. Cambridge University Press.

Beebe, L. (1988). Five sociolinguistic approaches to second language acquisition. Issues in Second Language Acquisition: Multiple Perspectives, 43-78.

Bhela, B. (1999). Native language interference in learning a second language: Exploratory case studies of native language interference with target language usage. International Education Journal, 1(1), 22-31.

Cook, V. (1999). Going beyond the native speaker in language teaching. TESOL Quarterly, 33(2), 185-209. https://doi.org/10.2307/3587717

Corder, S. P. (1967). The significance of learner's errors. IRAL-International Review of Applied Linguistics in Language Teaching, 5(1-4), 161-170. https://doi.org/10.1515/iral.1967.5.1-4.161

Corder, S. P. (1981). Error analysis and interlanguage (Vol. 112). Oxford: Oxford University Press.

Darus, S., \& Subramaniam, K. (2009). Error analysis of the written English essays of secondary school students in Malaysia: A case study. European Journal of Social Sciences, $8(3), 483-495$.

Dulay, B., \& Krashen, B. M. (1982). Language Two. Oxford University Press. 
Eid, J. (2006). The present Tense between English and Arabic: A comparative study.

Elkhafaifi, H. M., Eisele, J., Schultz, E., Krahl, G., \& Reuschel, W. (2001). Standard Arabic: An Elementary-Intermediate Course.

Ellis, R. (1994). The Study of Second Language Ac-quisition. Oxford: Oxford University Press.

Ellis, R., \& Shintani, N. (2014). Exploring language pedagogy through second language acquisition research. Oxen: Routledge. https://doi.org/10.4324/9780203796580

Erdoğan, V. (2005). Contribution of error analysis to foreign language teaching. Mersin Üniversitesi Ĕgitim Fakültesi Dergisi, 1(2).

Garrido, C. G., \& Rosado Romero, C. (2012). Errors in the use of English tenses. Íkala, Revista de Lenguaje Y Cultura, 17(3), 285-296.

Gass, S. (1979). Language transfer and universal grammatical relations. Language Learning, 29(2), 327-344. https://doi.org/10.1111/j.1467-1770.1979.tb01073.x

Gass, S. (1984). A review of interlanguage syntax: Language transfer and language universals. Language Learning, 34(2), 115-132. https://doi.org/10.1111/j.1467-1770.1984.tb01007.x

Heydari, P., \& Bagheri, M. S. (2012). Error analysis: Sources of L2 learners' errors. Theory and Practice in Language Studies, 2(8), 1583. https://doi.org/10.4304/tpls.2.8.1583-1589

Hourani, T. M. Y. (2008). An Analysis of the Common Grammatical Errors in the English Writing Made by 3rd Secondary Male Students in the Eastern Coast of the UAE.

Huddleston, R., \& Pullum, G. K. (2005). A student's introduction to English grammar. Cambridge University Press. https://doi.org/10.1017/CBO9780511815515

Jabeen, A., Kazemian, B., \& Mustafai, M. S. (2015). The Role of Error Analysis in Teaching and Learning of Second and Foreign Language. Education and Linguistics Research, 1(2), 52-62. https://doi.org/10.5296/elr.v1i2.8189

James, C. (1998). Errors in language learning and use: Exploring error analysis. Beijing: Foreign language Teaching and Research Press, 2001.

Karim, K., \& Nassaji, H. (2013). First language transfer in second language writing: An examination of current research. Iranian Journal of Language Teaching Research, 1(1), 117-134.

Karim, S. M. S., Fathema, F., \& Hakim, A. (2015). Common Errors on the Usage of Verbs in English Composition: A Case Study of Bangladeshi EFL Learners. Asian Journal of Educational Research, 3(2).

Kechoud, H. (2010). Students' approach to the translation of the present perfect from English into Arabic. Doctoral dissertation, Ministry of Higher Education.

Khazaal, E. N. (2009). Analysing Errors in learning the Present Continuous Tense: 
Associating Interference with Strategy of Instructions. College of Education for Women, 20(3), 686-701.

Lahlali, R., Serrhini, M. N., Friel, D., \& Jijakli, M. H. (2006). Vitro effects of water activity, temperature and solutes on the growth rate. Journal of Applied Microbiology, 101(3), 628-636. https://doi.org/10.1111/j.1365-2672.2006.02953.x

Larsen-Freeman, D., \& Long, M. H. (1991). An introduction to second language acquisition research. Longman Group.

Lee, J. J. (2005). The native speaker: An achievable model?. Asian EFL Journal, 7(2), 152-163.

Lennon, P. (2008). Contrastive analysis, error analysis, interlanguage. Bielefeld Introduction to Applied Linguistics. A Course Book. Bielefeld: Aisthesis Verlag.

Lightbown, P. M., Spada, N., Ranta, L., \& Rand, J. (2006). How languages are learned. Oxford University Press, USA.

López, W. C. (2009). Error analysis in a learner corpus: what are the learners' strategies?. In $A$ survey of corpus-based research (pp. 675-690).

Lott, D. (1983). Analysing and counteracting interference errors. ELT Journal, 37(3), 256-261. https://doi.org/10.1093/elt/37.3.256

Luo, X., \& Gao, J. (2011). Mechanisms Leading to Negative Transfer. Theory and Practice in Language Studies, 1(5), 507-510. https://doi.org/10.4304/tpls.1.5.507-510

Mahmoud, A. (2014). Simplification in Language Learning: What Do Learners Simplify?. Studies in English Language Teaching, 2(3), 275. https://doi.org/10.22158/selt.v2n3p275

Mansour, A. (2012). Difficulties in Translation of the English Present Perfect Simple and the Past Perfect Simple into Arabic. University of Anbar.

Meriläinen, L. (2010). Language transfer in the written English of Finnish students. University of Eastern Finland.

Mishra, K. C. (2005). Correction of Errors In English A Training Course. Sarup \& Sons.

Ngangbam, H. (2016). An Analysis of Syntactic Errors Committed by Students of English Language Class in the Writing Composition of Mutah University: A Case Study.

Noor, H. H. (1996). English Syntactic Errors by Arabic Speaking Learners: Reviewed.

Norris, J. (1987). Language learning and their errors. London: Macmillan Publisher.

Obeidat, M. M. (2014). A Linguistic Approach to Translating the English Past Perfect Aspect into Arabic. English Language and Literature Studies, 4(1), 62. https://doi.org/10.5539/ells.v4n1p62

Ouided, S. (2009). Problems in Translating Tenses from English into Arabic the Present Perfect: A Case Study. Mentourl University. 
Pongsiriwet, C., Fakhri, A., Obenauf, P. A., Deaton, D. W. L., \& Bower, W. S. (2001). Relationships among grammatical accuracy, discourse features, and the quality of second language writing. The case of Thai EFL learners, Ann Arbor, 1001(48), 106-136.

Qassim, A. (2014). Translation grammatically viewed. University of Baghdad.

Rahman, M. (2015). Linguistic transfer example from Arabic users of English. IJAR, 1(7), 804-806.

Richards, J. C. (1973). Error Analysis. London: Longman.

Richards, J. C. (1975). Simplification: A Strategy in the Adult Acquisition of A Foreign Language: An Example From Indonesian/Malaya1. Language Learning, 25(1), 115-126. https://doi.org/10.1111/j.1467-1770.1975.tb00112.x

Richards, J. C. (1978). Understanding second \& foreign language learning: issues \& approaches. Newbury House: Massachusetts.

Ringbom, H. (1987). The role of the first language in foreign language learning (Vol. 34). Multilingual Matters Ltd.

Ringbom, H. (1992). On L1 Transfer in L2 Comprehension and L2 Production. Language learning, 42(1), 85-112. https://doi.org/10.1111/j.1467-1770.1992.tb00701.x

Rivers, M. W. (1968). Teaching Foreign Language Skil1s. Chicago: Chicago University Press

Ruschmann, C. M. F. (2010). Simplification strategies in learners of English as foreign language.

Sabbah, S. (2015) Negative Transfer: Arabic Language Interference to Learning English. https://doi.org/10.2139/ssrn.2844015

Schulz, E. (2004). A student grammar of modern standard Arabic. Cambridge: Cambridge University Press.

Scott, M. S., \& Tucker, G. R. (1974). Error Analysis abd English-Language Strategies of Arab students. Language Learning, 24(1), 69-97. https://doi.org/10.1111/j.1467-1770.1974.tb00236.x

Selinker, L. (1972). Interlanguage. IRAL-International Review of Applied Linguistics in Language Teaching, 10(1-4), 209-232. https://doi.org/10.1515/iral.1972.10.1-4.209

Selinker, L., \& Gass, S. (2008). Second language acquisition: An introductory course. Taylor $\&$ Francis.

Shanks, D. R., Lamberts, K., \& Goldstone, R. L. (2005). Implicit learning. Handbook of Cognition, 202-220. https://doi.org/10.4135/9781848608177.n8

Sompong, M. (2013). Error Analysis. https://doi.org/10.1155/2013/840632

Swan, M. (1992). Practical English usage. New-York. 


\section{Macrothink}

International Journal of Linguistics

ISSN 1948-5425

2020, Vol. 12, No. 5

Takashima, H. (1992). Transfer, Overgeneralization and Simplification in Second Language Acquisition. A case study in Japan. IRAL-International Review of Applied Linguistics in Language Teaching, 30(2), 97-120. https://doi.org/10.1515/iral.1992.30.2.97

Tarone, E., Swierzbin, B., \& Bigelow, M. (2006). Impact of Literacy Level on Features of Interlanguage in Oral Narratives. Rivista di Psicolinguistica Applicata, 6(3), 1000-1013.

Tenfjord, K., Johansen, H., \& Hagen, J. E. (2006). The "Hows" and the "Whys" of Coding Categories in a Learner Corpus (or "How and Why an Error-Tagged Learner Corpus is not'ipso facto'One Big Comparative Fallacy"). Rivista di Psicolinguistica Applicata, 6(3), 1000-1016.

Thomas, J. (2014). Case Study of Error Analysis of the Usage of Tense in English by I Year Engineering Students from Tamil Medium School.

Touchie, H. Y. (1986). Second language learning errors their types, causes, and treatment. JALT Journal, 8(1), 75-80.

Tushyeh, H. Y. (1996). Linguistic problems facing Arab learners of English. Institut Voor Togepaste Linguistik, 1(11-12), 109-117. https://doi.org/10.1075/itl.111-112.05tus

Valero, L. A., Fernández, E. E., Iseni, A., \& Clarkson, C. P. (2008). Teachers' attitudes towards correcting students' written errors and mistakes. Porta Linguarum, 10, 21-30.

Wee, R., Sim, J., \& Jusoff, K. (2010). Verb-form errors in EAP writing. Educational Research and Reviews, 5(1), 16.

Wei, X. (2008). Implication of IL fossilization in second language acquisition. English Language Teaching, 1(1), 127. https://doi.org/10.5539/elt.v1n1p127

Wightwick, J., \& Gaafer, M. (2012). Practice Makes Perfect Arabic Verb Tenses: Arabic verbs and essentials of grammar: McGraw-Hill Professional. McGraw, Hill companies.

Wightwick, J., \& Mahmoud, G. (2008). Hill Companies, McGraw. New York ntials of Grammar Esse

Xie, F., \& Jiang, X. M. (2007). Error analysis and the EFL classroom teaching. Online Submission, 4(9), 10-14.

Yordchim, S., \& Gibbs, T. J. (2014). Error Analysis of English Inflection among Thai University Students. World Academy of Science, Engineering and Technology. International Journal of Social, Behavioral, Educational, Economic, Business and Industrial Engineering, 8(7), 2177-2180.

Zawahreh, F. A. S. (2012). Applied Error Analysis of Written Production of English Essays of Tenth Grade Students in Ajloun Schools. Jordan.International Journal of Learning and Development, 2(2), 280-299. https://doi.org/10.5296/ijld.v2i2.1680

Zhang, M. (2011). Error Analysis and Interlanguage. Focus, 1, 85-93.

Zhiri, Y. (2014). The Translation of Tense and Aspect from English into Arabic by Moroccan 
Undergraduates: Difficulties and Solutions. Arab World English Journal, 5(4).

\section{Appendix A}

Arabic sentences with their translations into English

\begin{tabular}{|c|c|c|}
\hline Number & Arabic sentence & English translation \\
\hline $1-$ & $\begin{array}{l}\text { أخي لم يستطع أن يفتح الباب لأنه كان قد أضاع المفاتيح } \\
\text { Ahki lam yastate an yafth albab lannahu } \\
\text { kana qad athaa almafateeh }\end{array}$ & $\begin{array}{l}\text { My brother could not open the } \\
\text { door, because he had lost the } \\
\text { keys. }\end{array}$ \\
\hline $2-$ & $\begin{array}{l}\text { إني ابحث عن مفاتيح السيارة منذ صباح الأمس حتى الآن } \\
\text { Enni abhathu an mafateeh assayara } \\
\text { munthu sabah alams hatta alaan }\end{array}$ & $\begin{array}{l}\text { I have been looking for my car's } \\
\text { keys since yesterday morning so } \\
\text { far. }\end{array}$ \\
\hline $3-$ & $\begin{array}{l}\text { بالأمس عند الساعة } 3 \text { مساء كنا نلعب كرة السلة } 3 \text { masaa kunna nalabu } \\
\text { Bilams enda assaa } 3 \text { kuratu assalla }\end{array}$ & $\begin{array}{l}\text { Yesterday at 3P.M, we were } \\
\text { playing basketball. }\end{array}$ \\
\hline 4- & $\begin{array}{l}\text { أخي يتعلم اللغة الانجليزية منذ ثلاثة أعوام حتى الآن } \\
\text { Ahki yatalamu alinglisia munthu thalathat } \\
\text { aauam hatta alaan }\end{array}$ & $\begin{array}{l}\text { My brother has been learning } \\
\text { English for three years so far. }\end{array}$ \\
\hline $5-$ & $\begin{array}{l}\text { البارحة عند الساعة 10، كنت أثناهد المباراة على التلفاز } \\
\text { Albariha enda assaa } 10 \text { kuntu aushahidu } \\
\text { almubarat ala attilfaz }\end{array}$ & $\begin{array}{l}\text { Last night at 10P.M, I was } \\
\text { watching the match on the } \\
\text { television. }\end{array}$ \\
\hline 6- & $\begin{array}{l}\text { إني أذاكر منذ ساعتين حتى الآن } \\
\text { Inni authakeru munthu sateen hatta alaan }\end{array}$ & $\begin{array}{l}\text { I have been studying for two } \\
\text { hours up to now }\end{array}$ \\
\hline 7- & $\begin{array}{l}\text { البارحة عند الساعة } 9 \text { مساء كنت اطبخ وجبة العشاء } \\
\text { Albariha enda assaa } 9 \text { masaa kuntu } \\
\text { atbukhu wajbat alasha lidhiauf }\end{array}$ & $\begin{array}{l}\text { Last night at } 9 \text { P.M, I was } \\
\text { cooking the dinner for guests. }\end{array}$ \\
\hline 8- & $\begin{array}{l}\text { نحن نتدرب في شركة النفط منذ اسبو عين } \\
\text { Nahnu natadarbu fi sharikiti alnift munthu } \\
\text { isboain }\end{array}$ & $\begin{array}{l}\text { We have been training in the oil } \\
\text { company for two weeks. }\end{array}$ \\
\hline 9- & $\begin{array}{l}\text { عندما وصلت المكتبة كان صديقي قد ذهب } \\
\text { Endma wasaltu almaktaba kana sadeqi qad } \\
\text { thahab }\end{array}$ & $\begin{array}{l}\text { When I arrived at the library, my } \\
\text { friend had already gone. }\end{array}$ \\
\hline $10-$ & $\begin{array}{l}\text { عندما بدأت زوجني بتحضير العشاء كانت المبار اة قدات } \\
\text { Endma badat zojati biththeer alasha kanat } \\
\text { almubarah qad badat }\end{array}$ & $\begin{array}{l}\text { When my wife began to prepare } \\
\text { the dinner, the match had started. }\end{array}$ \\
\hline
\end{tabular}




\begin{tabular}{|c|c|c|}
\hline 11- & $\begin{array}{l}\text { عندما وصل أبي كانت أمي قد حضرت وجبة لذيذة له } \\
\text { Endma wasala abi kanat ummi qad } \\
\text { hatharat wajbah lathithah lahu }\end{array}$ & $\begin{array}{l}\text { When my father arrived, my } \\
\text { mother had prepared a delicious } \\
\text { meal for him. }\end{array}$ \\
\hline $12-$ & $\begin{array}{l}\text { ماذا كنت تفعل عند الساعة } 10 \text { في الليلة الماضية؛ } \\
\text { Matha kunta tafaalu enda assaatu } 10 \text { fi } \\
\text { allaila almadhia }\end{array}$ & $\begin{array}{l}\text { What were you doing last night } \\
\text { at } 10 \text { P.M? }\end{array}$ \\
\hline
\end{tabular}

\section{Copyrights}

Copyright for this article is retained by the author(s), with first publication rights granted to the journal.

This is an open-access article distributed under the terms and conditions of the Creative Commons Attribution license (http://creativecommons.org/licenses/by/4.0/) 